\title{
Gender Differences in Children's Math Self-Concept in the First Years of Elementary School
}

\author{
Sven Lindberg ${ }^{1,2}$, Janosch Linkersdörfer ${ }^{1,2}$, Jan-Henning Ehm ${ }^{1,2}$, Marcus Hasselhorn ${ }^{1,2,3}$ \& Jan Lonnemann ${ }^{1,2}$ \\ ${ }^{1}$ German Institute for International Educational Research (DIPF), Frankfurt, Germany \\ ${ }^{2}$ Center for Individual Development and Adaptive Education of Children at Risk (IDeA), Frankfurt, Germany \\ ${ }^{3}$ Institute for Psychology, Goethe-University, Frankfurt, Germany \\ Correspondence: Sven Lindberg, IDeA, Schloßstr. 29, 60486 Frankfurt am Main, Germany. Tel: \\ 49-069-24708-216. E-mail: s.lindberg@idea-frankfurt.eu
}

\author{
Received: February 17, 2013 Accepted: March 26, $2013 \quad$ Online Published: July 12, 2013 \\ doi:10.5539/jel.v2n3p1 URL: http://dx.doi.org/10.5539/jel.v2n3p1
}

\begin{abstract}
In the course of elementary school children start to develop an academic self-concept reflecting their motivation, thoughts, and feelings about a specific domain. For the domain of mathematics, gender differences can emerge which are characterized by a less pronounced math self-concept for girls. However, studies are rather sparse regarding the early years of elementary school education, hence, the point in time when such gender differences emerge yet remains a matter of debate. In our study, we found that the math self-concept of elementary school children $(n=81)$ declined from first to second grade. While no differences in math achievement were observed between girls and boys, it became apparent that girls' math self-concept was already less pronounced than the math self-concept of boys in the first years of elementary school. Our findings emphasize the importance of considering such gender differences even at the beginning of school education.
\end{abstract}

Keywords: elementary school, math self-concept, Math achievement, academic development

\section{Introduction}

Studies of cognitive development have revealed numerous factors (such as, quantity-number competencies, working memory, and phonological awareness) that are important for the successful unfolding of math ability and performance (e.g., Butterworth, 2010; Geary, 2000; Krajewski \& Schneider, 2009). However, besides these basal cognitive preconditions, motivational and affective aspects are important for individual math development (Lee, 2009). In this regard, academic self-concept has been demonstrated to be one of the most important constructs in the field of motivational research (Marsh \& Craven, 2006). It can be defined as a mental representation of one's abilities in a specific academic context and is formed by experiences in achievement reltated situations and the intearction between the environment and significant others (Shavelson et al., 1976). A positive self-concept is associated with high self-efficacy (Bong \& Skaalvik, 2003), cognitive and emotional engagement in school (Helmke, 1999), lasting learning and achievement motivation as well as academic effort (Guay, Ratelle, Roy, \& Litalien, 2010; Marsh \& Craven, 2006). Furthermore, previous research has shown that children's interest in future academic activities declines if those activities are not in accordance with their self-concept (Denissen, Zarrett, \& Eccles, 2007; Liben, Bigler, \& Krogh, 2001).

So far, research on children's academic self-concept has mainly focused on secondary school children (e.g., Marsh, 1986; 1990; Möller \& Köller, 2001; Möller, Streblow, Pohlmann, \& Köller, 2006) whereas studies on the first two years of elementary school are comparatively rare (Chapman \& Tunmer, 1997; Guay, Marsh, \& Boivin, 2003; Helmke \& van Aken, 1995; Möller, Pohlmann, Köller, \& Marsh, 2009). Results from these studies demonstrate that elementary school children are capable of reporting their self-perception of achievement from their school enrollment on (Marsh, Craven, \& Debus, 1991; Marsh, Ellis, \& Craven, 2002). Certainly, at this young age children tend to show an exceptional high level of academic self-concept since they still have difficulties in differentiating between actual and desired attributes and in using information from social comparisons for an adequate self-evaluation (Harter, 1999). As a consequence, the own abilities are estimated as relatively high and the early self-concept is thereby less associated with the actual achievement (Eccles, Wigfield, Harold, \& Blumenfeld, 1993; Helmke, 1999). In the process of academic development, children's self-reflection 
gets more performance oriented based on the reception of frequent competence-related feedback (Byrne \& Gavin, 1996; Marsh, 1985). Therefore, children's academic self-concept becomes more stable and it is more strongly associated with achievement at the end of elementary school (Harter, 1999; Lee, 2009).

The academic self-concept of girls and boys seems to develop differently. In the verbal domain, girls generate a comparable or even higher self-concept than boys (Herbert \& Stipek, 2005; Heyman \& Legare, 2004). In the mathematical domain, however, girls are more prone to develop a lower self-concept (Eccles, Wigfield, Harold, \& Blumenfeld, 1993; Fredericks \& Eccles, 2002). In the course of schooling, this discrepancy between girls and boys becomes even more pronounced (Helmke, 1998). However, so far findings concerning the question of when exactly these gender differences emerge are inconsistent. Although several studies suggest that gender differences initially occur at the end of elementary school (Marsh, Craven, \& Debus, 1991; Herbert \& Stipek, 2005; Muzzatti \& Agnoli, 2007), a few findings indicate that girls already demonstrate a less pronounced math self-concept in the first two years of elementary school (Eccles, Wigfield, Harold, \& Blumenfeld, 1993; Ehm, Duzy, \& Hasselhorn, 2011; Jacobs, Lanza, Osgood, Eccles, \& Wigfield, 2002).

Therefore, additional research is needed to investigate the development of the self-concept from the first grade on. Especially the first two years of schooling are a critical period for self-concept development. As soon as they enter school, children get feedback from significant others, start to compare their own achievements to the achievements of other students (inter-individual comparison) and their own achievements in different domains (intraindividual comparison; Marsh, 1989). Moreover, children are confronted early on with gender stereotypes that might influence their self-concept and achievement (Cvencek, Meltzoff, \& Greenwald, 2011; Dweck, 2007). The aim of this longitudinal study is to look for possible gender differences that might emerge in the formation of the math-related self-concept. Thus, we focus on the first two years of elementary school to reveal when potential gender differences might occur regarding self-perceived and actual math ability and to examine how these variables are interrelated in this period.

\section{Method}

\subsection{Participants and Procedure}

The participants were 81 ( 42 female) elementary school children recruited in the area of Frankfurt in Germany. All children provided data on the two measurement points (mean age $=7.2$ at $\mathrm{T} 1$ and 8.2 at T2) in first and second grade. Measures were conducted in a single test setting by trained student assistants.

\subsection{Math Achievement}

To test mathematical school achievement, the standardized German test for the availability of basic facts in arithmetic (DIRG, Grube, Weberschock, Stuff, \& Hasselhorn, 2010) was applied in the first and second grade. We used subtest of DIRG that includes 110 simple addition problems with solutions $\leq 10$ and without ties (e.g., $2+2$ or $4+4)$. These simple addition problems were used to assure that all children were able to solve the tasks. Children were asked to write down as many solutions as possible in four minutes. Raw scores were transformed to percentile scores according to the norms applicable for the respective school year.

\subsection{Math Self-Concept}

In order to assess children's self-concept, we used the math subscale from an instrument suitable for elementary school children (Ehm, Duzy, \& Hasselhorn, 2011). The self-concept measure is based on the self-concept model suggested by Shavelson, Hubner, and Stanton (1976); it was developed following the Self-Description Questionnaire (SDQ, Marsh, 1990) and the self-concept scales of the LOGIK study (Helmke \& van Aken, 1995). Children were asked to respond to six positively worded items pursuant to a seven-point scale (ranging from $1=$ very poor to 7 = very good; higher values indicating higher self-concepts). The points of the scale were illustrated via small stick-figures (instead of digits) representing classmates. The children's task was to label one of the stick-figures representing their own math ability. One of the 6 items required explicit social comparison processes: Children were asked to rate their relative position in math compared to their classmates (e.g., "In math, I am the worst/best"). The items' design reflected both evaluative ("In math, I am very poor/very good") as well as emotional ("Math is no fun/a lot of fun") beliefs about one's math achievement (Burnett, 1994). The instructions and every single item were read aloud to the children and an example question was administered to illustrate the questionnaire procedure. The internal consistency (Cronbach's alpha) of the scale score was high, with values of .87 (grade 1) and .89 (grade 2).

\section{Results}

Table 1 shows means and standard deviations of children's math self-concept and ability separately for girls and boys at T1 and T2. The internal consistency (Cronbach's alpha) of the math self-concept scale score was high, 
with values of .87 (grade 1) and .89 (grade 2). We conducted two (measurement time point) $\mathrm{x}$ two (gender) factorial ANOVA's with repeated measures to analyze children's math self-concept and math achievement respectively. The Levene-Test indicates that the variances were equal for girls and boys in grade $1 F(1,79)=.023$, $n s$ and grade $2 F(1,79)=1.481, n s$. For the math self-concept, significant main effects for measuring time, $F(1$, $79)=11.23, p<1.001, \eta^{2}=.12$ and gender, $F(1,79)=7.14, p<.01, \eta^{2}=.08$ were found, whereas the interaction measuring time $\mathrm{x}$ gender was not significant. The main effect for measuring time indicated that the math self-concept for all children declined from first to second grade. The significant main effect for gender revealed a difference between girls and boys regarding their math self-concept. According to the bonferroni post hoc simple effects, differences between girls and boys were not significant in the first but in the second grade (see Table 1). Furthermore, whereas the math self-concept of the boys declined only marginally $(p=.09)$, the decline was significant for the girls $(p<.05)$. In the ANOVA of math achievement, both main effects and the interaction were not significant showing that children's math achievement remained stable between $\mathrm{T} 1$ and $\mathrm{T} 2$ and no gender difference was detectable.

Table 1. Descriptive statistics and comparisons of the observed variables

\begin{tabular}{lccccccc}
\hline \multicolumn{10}{c}{ Girls $(n=42)$} & \multicolumn{6}{c}{ Boys $(n=39)$} \\
\hline Math & $\boldsymbol{M}$ & $\boldsymbol{S D}$ & $\boldsymbol{M}$ & $\boldsymbol{S D}$ & $\boldsymbol{F}$ & $\boldsymbol{p}$ & $\eta^{2}$ \\
self-concept T1 & 5.57 & 1.37 & 6.03 & 1.13 & 2.71 & .103 & .033 \\
self-concept T2 & 4.82 & 1.51 & 5.60 & 1.19 & 6.65 & .012 & .078 \\
achievement T1 & 49.17 & 29.26 & 56.79 & 30.45 & 1.31 & .255 & .016 \\
achievement T2 & 47.83 & 28.78 & 56.38 & 24.57 & 2.05 & .156 & .025
\end{tabular}

Note. Math self-concept and self-evaluation range from 1 to 7 . According to percentile range, math achievement ranged from 0 to 100 .

Results of a correlation analysis (Table 2) showed a distinct association between first grade math achievement and second grade self-concept for all children. Moreover, the math achievement scores of T1 and T2 were fouuund to be closely related. The first grade math self-concept was also related with the second grade math self-concept but this connection was only significant for boys whereas girls' first grade math self-concept was not significantly correlated with their second grade self-concept. Comparing the respective correlation coefficients for both groups (see Millsap et al., 1990), we found a significant difference $(p<0.01$; two-sided).

Table 2. Correlation matrix for the observed variables

\begin{tabular}{lllll}
\hline & & 1. SC1 & 2. SC2 & 3. MA1 \\
\hline 1. Math self-concept T1 (SC1) & & - & - & - \\
2. Math self-concept T2 (SC2) & Overall & $.30^{*}$ & - & - \\
& Girls & .05 & - & - \\
& Boys & $.62^{* *}$ & - & - \\
3. Math achievement T1 (MA1) & Overall & .15 & $.33^{* *}$ & - \\
& Girls & .15 & .30 & - \\
& Boys & .12 & $.32^{*}$ & - \\
4. Math achievement T2 (MA2) & Overall & .07 & .17 & $.74^{* *}$ \\
& Girls & .10 & .09 & $.71^{* *}$ \\
& Boys & -.02 & .19 & $.77^{* *}$ \\
\hline
\end{tabular}

$* p<.05 ; * * p<.01$ (two-sided)

\section{Discussion}

In this study, we investigated children in the first two years of elementary school aiming to detect possible gender differences in the formation of the math self-concept. In accordance with previous findings, children in the first year of elementary school reported a positive math self-concept (Helmke, 1999; Kammermeyer \& 
Martschinke, 2006), which decreased in second grade (Byrne \& Gavin, 1996; Marsh, 1985). Our results confirmed the assumption that boys and girls start to differ early in their math- self-concept: while no significant differences could be detected in first grade, the self-concept of the girls was significantly lower than the self-concept of the boys in second grade (for similar results, see, Eccles et al., 1993; Ehm et al., 2011; Fredericks \& Eccles, 2002). As shown before, these gender differences seem to be independent from actual math achievement scores, which were comparable between male and female children in both grades (Hyde, Lindberg, Linn, Ellis, \& Williams, 2008; Herbert \& Stipek, 2005). The correlation patterns showed that math achievement was highly related between the two grades. Although the self-concept measured in the first grade seemed to be highly correlated with the self-concept measured in second grade, this relation was only found in boys. Moreover, no significant correlation could be found between the self-concept and math achievement within grades, but an association was detectable between first grade math achievement and second grade self-concept. However, whereas the correlation for girls slightly failed the significance level, the correlation for the boys was significant.

In our study, girls showed lower math self-concept scores and thereby started to differ significantly from boys in the second grade. A possible reason for such differences might be that, even at this early stage of academic development, girls were confronted with culturally communicated messages stating that math is a "boys' affair and not so important for girls" (Dweck, 2007; Guiso, Monte, Sapienza, \& Zingales, 2008; Steele, 2003). Recent findings suggest that gender differences in the math self-concept in school may stem from an already established gender bias that emerges in preschool even before math achievement can be measured (Cvencek et al., 2011). Interestingly, in our study the math self-concept of the girls declined stronger than that of the boys (despite no differences in actual math performance in both years). According to the findings of Cvencek and colleagues (2011) this increasing gender gap in math self-concept may later on lead to actual gender differences in math achievement.

No correlations could be found between math self-concept and achievement scores within the first or within the second grade. These results are in line with previous findings reporting only weak or no associations between self-concept and achievement for children in the early years of elementary school (Cahpman \& Tunmer, 1997; Ehm et al., 2011;). An interpretation of the missing connection is that some children tend to judge their performance overoptimistically before they receive grades and social comparisons arise (Hasselhorn, 2005; Marsh, Craven, \& Debus, 1991). When focusing on the correlation between the grades, it is noticeable that the math achievement measured in first grade seems to be related to the math self-concept in second grade. These findings can bee interpreted in the light of the skill-development approach by Guay, Marsh, and Boivin (2003) claiming that math achievement is a determinant of the math self-concept and not vice versa. However, since we only report bivariate correlations, this interpretation can be seen only as an assumption.

When focusing on the association between the first grade math self-concept and the second grade self-concept it seems that they are significantly related. On closer examination, it becomes apparent that this is true only for boys. Although all children seem to have an overoptimistic view of themselves when beginning school, it seems that girls' and boys' self-perception changes by different degrees. Boys already start with a slightly higher math self-concept in first grade and their decrease in self-concept from first to second grade is less pronounced than in girls. It might be that some of the girls begin earlier (in second grade) to be more self-critical or even start to be more realistic. Alternatively, the internal comparison (see I/E model, Marsh, 1989) might be stronger in some of the girls, so that verbal achievement has a negative effect on the math self-concept (Skaalvik \& Rankin, 1990). Moreover, as indicated by the findings of Cvencek, Meltzoff, and Greenwald (2011), perhaps some boys are already more identified with numbers and math than girls even before school entry and therefore also in first grade. Such early gender bias may have caused the missing link between first and second grade math self-concept in girls in our findings.

\subsection{Limitations}

Since we focused on the beginning of elementary school, our instruments had to be adapted to the requirements of early math education. In first grade, children are solely confronted with simple arithmetic tasks with an initial focus on addition (number range up to 10). Pursuant to transition to second grade, more advanced tasks are introduced (e.g., subtraction; number range above 10). Moreover, elementary school children learn number magnitude relations and play math games that include counting and estimating procedures. This illustrates that our achievement measure concentrated only on a limited part of the possible range of math-related activities in the early years of elementary school. However, simple addition is one of the most essential mathematical principals and it can be considered as precursor for further math learning. Furthermore, to analyze developmental processes in a longitudinal design, we aimed to use the same instruments in first and second grade for assessing math achievement and self-concept. Nevertheless, we are aware that besides the rather small sample size, the 
very focused instruments may disguise potentially significant results. Therefore, future studies should extend the measures adaptively with the course of schooling.

\subsection{Implications}

It seems that girls and boys differ in their math self-concept and perceive their math achievement in different ways. The results of our study demonstrate that although girls and boys do not differ regarding their math achievement in the early years of elementary school, the math self-concept of girls is less pronounced and declines stronger from first to second grade. This pattern implicates that girls might start to disconnect themselves from the school subject of math or from math-related abilities (Cvencek et al., 2011). As highlighted by recent studies with adults, people start to reject academic activities that are perceived as not corresponding to the self (Cheryan, Meltzoff, \& Kim, 2010; Cheryan, Plaut, Davies, \& Steele, 2009). Thus, it is essential to early counteract such gender differences in math self-concept that are not achievement-related. Moreover, Ahmed, Minnaert, Kuyper, and van der Werf (2012) emphasized the close relation of math self-concept with math anxiety and reported a very strong effect of the math self-concept on math anxiety. The authors conclude that previous negative experience with math might be responsible for the development of a dysfunctional math self-schema that can lead to a higher level of math anxiety. As a consequence, they recommend to enhance children's math self-concept early on to prevent later math anxiety. As our data show, this especially applies to girls.

The notion of promoting children's math self-concept to prevent gender-specific and unspecific math problems and anxiety seems in contrast to the view that it is necessary to foster children's realistic self-perception of their math ability. Certainly, it is important to obtain a balance between the generation of a positive view of one's own ability (acting against underestimation) and the danger of evoking an unrealistic overestimation of one's own achievement that may lead to lower learning efforts.

\section{Acknowledgements}

We would like to thank all the participating children. Moreover, we are grateful to our student assistants for their help with data collection and analysis. This research was funded by the Hessian initiative for the development of scientific and economic excellence (LOEWE).

\section{References}

Ahmed, W., Minnaert, A., Kuyper, H., \& van der Werf, G. (2012). Reciprocal relationships between math self-concept and math anxiety. Learning and Individual Differences, 22(3), 385-389. http://dx.doi.org/10.1016/j.lindif.2011.12.004

Alentine, J., DuBois, D., \& Cooper, H. (2004). The relation be- tween self-beliefs and academic achievement: A $\begin{array}{lllll}\text { meta-analytic review. } & \text { Educational }\end{array}$ http://dx.doi.org/10.1111/j.1559-1816.2003.tb02782.x

Bong, M., \& Skaalvik, E. M. (2003). Academic self-concept and self-efficacy: How different are they really? Educational Psychology Review, 15, 1-40. http://dx.doi.org/10.1023/A:1021302408382

Burnett, P. C. (1994). Self-concept and self-esteem in elementary school children. Psychology in School, 31, 164-171. http://dx.doi.org/10.1002/1520-6807(199404)31:2<164::AID-PITS2310310211>3.0.CO;2-U

Butterworth, B. (2010). Foundational numerical capacities and the origins of dyscalculia. Trends in Cognitive Sciences, 14, 534-541. http://dx.doi.org/10.1016/j.tics.2010.09.007

Byrne, B. M. (1996). Measuring self-concept across the life span: Issues and instrumentation. Washington DC: American Psychological Association. http://dx.doi.org/10.1037/10197-000

Byrne, B. M., \& Gavin, D. A. W. (1996). The Shavelson Model revisited: Testing for the structure of academic self-concept across pre-, early, and late adolescents. Journal of Educational Psychology, 88, 215-228. http://dx.doi.org/10.1037/0022-0663.88.2.215

Chapman, J. W., \& Tunmer, W. E. (1997). A longitudinal study of beginning reading achievement and reading self-concept. British Journal of Educational Psychology, 67, 279-291. http://dx.doi.org/10.1111/j.2044-8279.1997.tb01244.x

Cheryan, S., Meltzoff, A. N., \& Kim, S. (2011). Classrooms matter: The design of virtual classrooms influences gender disparities in computer science classes. Computers \& Education, 57, 1825-1835. http://dx.doi.org/10.1016/j.compedu.2011.02.004

Cheryan, S., Plaut, V. C., Davies, P., \& Steele, C. M. (2009). Ambient belonging: How stereotypical cues impact 
gender participation in computer science. Journal of Personality and Social Psychology, 97, 1045-1060. http://dx.doi.org/10.1037/a0016239

Cvencek, D., Meltzoff, A. N., \& Greenwald, A. G. (2011). Math-gender stereotypes in elementary school children. Child Development, 82(3), 766-779. http://dx.doi.org/10.1111/j.1467-8624.2010.01529.x

Denissen, J. J. A., Zarrett, N. R., \& Eccles, J. S. (2007). I like to do it, I'm able, and I know I am: Longitudinal couplings between domain-specific achievement, self- concept, and interest. Child Development, 78, 430-447. http://dx.doi.org/10.1111/j.1467-8624.2007.01007.x

Dweck, C. S. (2007). Is math a gift? Beliefs that put females at risk. In S. J. Ceci, \& W. M. Williams (Eds.), Why aren't more women in science? Top researchers debate the evidence (pp. 47-55). Washington, DC: American Psychological Association. http://dx.doi.org/10.1037/11546-004

Eccles, J., Wigfield, A., Harold, R. D., \& Blumenfeld, P. (1993). Age and Gender Differences in Children's Selfand Task Perceptions during Elementary School. Child Development, 64, 830-847. http://dx.doi.org/10.2307/1131221

Ehm, J.-H., Duzy, D., \& Hasselhorn, M. (2011). Das akademische Selbstkonzept bei Schulanfängern. Frühe Bildung, 0, 37-45. [The academic self-concept in children beginning school education] http://dx.doi.org/10.1026/2191-9186/a000008

Fredericks, J. A., \& Eccles, J. S. (2002). Children's competence and value beliefs from childhood through adolescence: Growth trajectories in two male-sex-typed domains. Developmental Psychology, 38, 519-533. http://dx.doi.org/10.1037/0012-1649.38.4.519

Geary, D. C. (2000). From infancy to adulthood: The development of numerical abilities. European Child \& Adolescent Psychiatry, 9, 11-16. http://dx.doi.org/10.1007/s007870070004

Grube, D., Weberschock, U., Baum, M., \& Hasselhorn, M. (2010). Diagnostisches Inventar zu Rechenfertigkeiten im Grundschulalter (DIRG). Göttingen: Hogrefe. [Diagnostic inventory on calculation abilities in elementary-school aged children]

Guay, F., Marsh, H. W., \& Boivin, M. (2003). Academic Self-Concept and Academic Achievement: Developmental Perspectives on Their Causal Ordering. Journal of Educational Psychology, 95, 124-136. http://dx.doi.org/10.1037/0022-0663.95.1.124

Guay, F., Ratelle, C. F., Roy, A., \& Litalien, D. (2010). Academic self-concept, autonomous academic motivation, and academic achievement: Mediating and additive effects. Learning and Individual Differences, 20, 644-653. http://dx.doi.org/10.1016/j.lindif.2010.08.001

Guiso, L., Monte, F., Sapienza, P., \& Zingales, L. (2008). Culture, gender, and math. Science, 320, 1164-1165. http://dx.doi.org/10.1126/science.1154094

Harter, S. (1999). The construction of the self: A developmental perspective. New York: The Guilford Press.

Hasselhorn, M. (2005). Lernen im Altersbereich zwischen 4 und 8 Jahren: Individuelle Voraussetzungen, Entwicklungsbesonderheiten, Diagnostik und Förderung. In T. Guldimann, \& B. Hauser (Eds.), Bildung 4bis 8-jähriger Kinder (pp. 77-88). Münster: Waxmann. [Learning in children aged four to eight years: individual prerequisites, diagnosis and support]

Helmke, A. (1998). Vom Optimisten zum Realisten? Zur Entwicklung des Fähigkeitsselbstkonzepts vom Kindergarten bis zur 6. Klassestufe. In W. Schneider, \& F. E. Weinert (Eds.), Entwicklung im Kindesalter (pp. 116-132). Weinheim: Beltz [From realism to optimmism? On the development of academic self-concepts from kindergarten to sixth grade]

Helmke, A. (1999). From optimism to realism? Development of children's academic self-concept from kindergarten to grade six. In W. Schneider, \& F. E. Weinert (Eds.), Individual Development From 3 to 12. Findings From the Munich Longitudinal Study (pp. 198-221). Cambridge: University Press.

Helmke, A., \& van Aken, M. (1995). The causal ordering of academic achievement and self-concept of ability during elementary school: A longitudinal study. Journal of Educational Psychology, 87, 624-637. http://dx.doi.org/10.1037/0022-0663.87.4.624

Herbert, J., \& Stipek, D. T. (2005). The emergence of gender differences in children's perceptions of their academic competence. Applied Developmental Psychology, 26, 276-295. http://dx.doi.org/10.1016/j.appdev.2005.02.007 
Heyman, G. D., \& Legare, C. H. (2004). Children's beliefs about gender differences in the academic and social domains. Sex Roles, 50, 227-239. http://dx.doi.org/10.1023/B:SERS.0000015554.12336.30

Hyde, J. S., Lindberg, S. M., Linn, M. C., Ellis, A. B., \& Williams, C. C. (2008). Gender similarities characterize math performance. Science, 321, 494-495. http://dx.doi.org/10.1126/science.1160364

Jacobs, J. E., Lanza, S., Osgood, D. W., Eccles, J. S., \& Wigfield, A. (2002). Changes in children's self-competence and values: Gender and domain differences across grades one through twelve. Child Development, 73, 509-527. http://dx.doi.org/10.1111/1467-8624.00421

Kammermeyer, G., \& Martschinke, S. (2006). Selbstkonzepte- und Leistungsentwicklung in der Grundschule Ergebnisse aus der KILIA-Studie. Empirische Pädagogik, 20(3), 245-259. [Self-concept and achievement development in elementary school. Findings from the KILIA study]

Krajewski, K., \& Schneider, W. (2009). Exploring the impact of phonological awareness, visual-spatial working memory, and preschool quantity-number competencies on mathematics achievement in elementary school: findings from a 3-year longitudinal study. Journal of experimental child psychology, 103(4), 516-531. http://dx.doi.org/10.1016/j.jecp.2009.03.009

Lee, J. (2009). Universals and specifics of math self-concept, math self-efficacy, and math anxiety across 41 PISA 2003 participating countries. Learning and Individual Differences, 19(3), 355-365. http://dx.doi.org/10.1016/j.lindif.2008.10.009

Liben, L. S., Bigler, R. S., \& Krogh, H. R. (2001). Pink and blue collar jobs: Children's judgments of job status and job aspirations in relation to sex of worker. Journal of Experimental Child Psychology, 79, 346-363. http://dx.doi.org/10.1006/jecp.2000.2611

Marsh, H. W, Craven, R. G., \& Debus, R. (1991). Self-Concepts of Young Children 5 to 8 Years of Age: Measurement and Multidimensional Structure. Journal of Educational Psychology, 83, 377-392. http://dx.doi.org/10.1037/0022-0663.83.3.377

Marsh, H. W. (1985). Age and sex effects in multiple dimensions of preadolescent self-concept: A replication and extension. Australian Journal of Psychology, 37, 197-204. http://dx.doi.org/10.1080/00049538508256398

Marsh, H. W. (1986). Verbal and Math Self-Concepts: An Internal/External Frame of Reference Model. American Educational Research Journal, 23, 129-149.

Marsh, H. W. (1990). Influences of internal and external frames of reference on the formation of math and English self-concepts. Journal of Educational Psychology, 82, 107-116. http://dx.doi.org/10.1037/0022-0663.82.1.107

Marsh, H. W. (1990). The structure of academic self-concept: The Marsh/Shavelson Model. Journal of Educational Psychology, 82, 623-636. http://dx.doi.org/10.1037/0022-0663.82.4.623

Marsh, H. W., \& Craven, R. G. (2006). Reciprocal Effects of Self-Concept and Performance From a Multidimensional Perspective. Beyond Seductive Pleasure and Unidimensional Perspectives. Perspectives on Psychological Science, 1, 133-163. http://dx.doi.org/10.1111/j.1745-6916.2006.00010.x

Marsh, H. W., Ellis, L. A., \& Craven, R. G. (2002). How Do Preschool Children Feel About Themselves? Unraveling Measurement and Multidimensional Self-Concept Structure. Developmental Psychology, 38, 376-393. http://dx.doi.org/10.1037/0012-1649.38.3.376

Millsap, R. E., Zalkind, S. S., \& Xenos, T. (1990). Quick-reference tables to determine the significance of the difference between two correlation coefficients from two independent samples. Educational and Psychological Measurement, 50, 297-307. http://dx.doi.org/10.1177/0013164490502008

Möller, J., \& Köller, O. (2001). Dimensional Comparison: An Experimental Approach to the Internal/External Frame of Reference Model. Journal of Educational Psychology, 93, 826-835. http://dx.doi.org/10.1037/0022-0663.93.4.826

Möller, J., Pohlmann, B., Köller, O., \& Marsh, H. W. (2009). A Meta-Analytic Path Analysis of the Internal/External Frame of Reference Model of Academic Achievement and Academic Self-Concept. Review of Educational Research, 79, 1129-1167. http://dx.doi.org/10.3102/0034654309337522

Möller, J., Streblow, L., Pohlmann, B., \& Köller, O. (2006). An extension to the internal/external frame of reference model to two verbal and numerical domains. European Journal of Psychology of Education, 21, 467-487. http://dx.doi.org/10.1007/BF03173515 
Muzzatti, B., \& Agnoli, F. (2007). Gender and mathematics: Attitudes and stereotype threat susceptibility in Italian children. Developmental Psychology, 43, 747-759. http://dx.doi.org/10.1037/0012-1649.43.3.747

Shavelson, R. J., Hubner, J. J., \& Stanton, G. C. (1976). Self-concept: validation of construct interpretations. Review of Educational Research, 46, 407-444.

Skaalvik, E. M., \& Rankin, R. J. (1990). Math, verbal, and general academic self-concept: The internal/external frame of reference model and gender differences in self-concept structure. Journal of Educational Psychology, 82, 546-554. http://dx.doi.org/10.1037/0022-0663.82.3.546

Steele, J. (2003). Children's gender stereotypes about math: The role of stereotype stratification. Journal of Applied Social Psychology, 33, 2587-2606.

Wigfield, A., \& Eccles, J. S. (2000). Expectancy-value theory of achievement motivation. Contemporary Educational Psychology, 25, 68-81. http://dx.doi.org/10.1006/ceps.1999.1015

\section{Copyrights}

Copyright for this article is retained by the author(s), with first publication rights granted to the journal.

This is an open-access article distributed under the terms and conditions of the Creative Commons Attribution license (http://creativecommons.org/licenses/by/3.0/). 